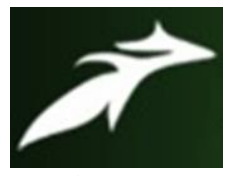

Athira Pradeep et al, International Journal of Advances in Agricultural Science and Technology,

Vol.8 Issue.8, August-2021, pg. 52-59

ISSN: 2348-1358

Impact Factor: 6.057

NAAS Rating: 3.77

\title{
Constraints faced by the Respondents in Cultivation of Betel Vine in Malappuram District of Kerala
}

\author{
Athira Pradeep ${ }^{1}$; Dr. Syed H Mazhar ${ }^{2}$; Prof. (Dr.) Jahanara ${ }^{3}$ \\ ${ }^{1}$ M.Sc. Ag. (Agricultural Extension and communication), SHUATS (Prayagraj) \\ ${ }^{2}$ Associate Professor, Department of Agriculture Extension and Communication, SHUATS (Prayagraj) \\ ${ }^{3}$ Head, Department of Agriculture Extension and Communication, SHUATS (Prayagraj) \\ Author's e-mail: athuthiruvonam@gmail.com
}

DOI: 10.47856/ijaast.2021.v08i8.005

\begin{abstract}
Betel vine (Piper betel L. ) in India is grown as an important cash crop across the states, of, Kerala, and Tamil Nadu, Assam, Bihar, Madhya Pradesh, Maharashtra, Odisha, Tripura ,Andhra Pradesh, Karnataka, Uttar Pradesh and West Bengal. A study was undertaken in Malappuram district of Kerala for analysis of constraints faced by the farmers in betel vine cultivation covering Tanur block taking six villages selected purposively where the crop is grown as a major crop. A total 120 betel vine growers were selected randomly from six villages. It is observed that nearly half of the respondents felt the constraints were severe $(45 \%)$ in betel vine cultivation, followed by not severe $(31.66 \%)$ and very severe $(\mathbf{2 3 . 3 3 \%})$. Most of the respondents experienced labour shortage or high labour cost as the most problematic constraint, the study further indicated that the second most important constraint found was price fluctuation followed by water scarcity, transportation and insects and diseases.
\end{abstract}

Keywords: Constraints, Betel vine cultivation

\section{Introduction}

Betel vine (Piper betel L) is an important commercial and heritage crop of our country. It belongs to the family piperaceae. It is cultivated intensively for the sake of its leaves. Usage of betel leaf is intricately woven into fabric of Indian culture and tradition (Pavithra, 2016). Betel leaves are integral part of all social, religious and cultural activities and also regarded as the symbol of hospitality. Piper betel is blessed as evergreen and perennial plant that God has created and has given the shape of his own heart. Betel vine is native to central and eastern Malaysia and tropical Asia. Betel vine is known by its many names as pan in Hindi, Tambula in 


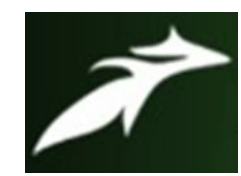

Athira Pradeep et al, International Journal of Advances in Agricultural Science and Technology, Vol.8 Issue.8, August-2021, pg. 52-59

ISSN: 2348-1358

Impact Factor: 6.057

NAAS Rating: 3.77

Sanskrit, Villayadele in Kannada, Vettilakkoti in Malayalam, Vettilai in Tamil, Tamalapaku in Telugu, Videch-pan in Marathi, Nagarbel in Gujarati and pan in Bengali. In foreign languages, it is known as Tanbol in Arabic and Burg-e-Tambol in Persisan.

Betel leaves are the most important plant part and are of medicinal, religious and ceremonial value in South East Asia. In India it is customary to serve betel leaf on various social, cultural and religious occasions and is also offered to guests as a mark of respect. The plant is much more popular in India than in any other country of the world since the antiquity. The betel leaves are very nutritive and contain a substantial amount of vitamins and minerals. The economic aspects of the crop prove that betel leaf is one of the most promising commercial crops capable of attracting a substantial amount of foreign exchange to the country. The medicinal properties of the pan were recognized during 600 A.D. when the ayurvedic system of medicine came into practice. The primary constituents of betel leaves are vitamin B, C and carotene.

Betel vine is an important medicinal and recreational plant in South East Asia. The most probable place of origin of betel vine is Malaysia but today the plants are also cultivated in India, Sri Lanka, Burma and Nepal. Chewing of betel leaves is an ancient habit of the people residing in the subtropical countries. It is used in a number of traditional remedies for the treatment of stomach ailments, infections and as a general tonic. It is often chewed in combination with the betel nut as a stimulatory. Some evidence suggests betel leaves have immune boosting properties as well as anti-cancer properties. Betel vine plays a significant role in the social and cultural aspects of India. These leaves are also in great demand in several other countries of the world. Betel vine cultivation is highly labour intensive and particularly suited to small holdings. So it could be a good option for the landless farmer to go for leasing and cultivation which could provide them a good return in income.

\section{Research Methodology}

The present study was carried out to identify constraints of Betel vine growers in Malappuram district of Kerala. Purposive sampling procedure was employed for selection of block and villages. Random sampling was used for selection of betel vine growers. This study has been conducted in the Malappuram district of Kerala covering Tanur block. Villages were selected purposively because these villages are leading in terms of area and production of betel vine in the district and also presence of wholesale market in Tirur town. A sample size 120 betel vine growers were randomly selected from six villages. Although betel vine cultivation is profitable, but many farmers were switching over to other crops from betel vine due to labour shortage and also high price fluctuation uncertainty in the local market .Considering this, the study was 


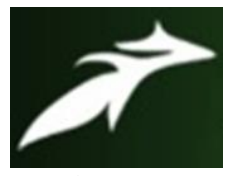

Athira Pradeep et al, International Journal of Advances in Agricultural Science and Technology, Vol.8 Issue.8, August-2021, pg. 52-59

ISSN: 2348-1358

Impact Factor: 6.057

NAAS Rating: 3.77

organized with an objective to study the constraints faced by farmers in cultivation according to ranking. The primary data were collected from the sample farmers on pre-structured schedules through personal interview method. For measurement of these variables a list of various constraints was prepared in consultation with the farmers, teachers and researchers. In order to study the frequency of constraints, one frequency continuum was prepared against each constraint very severe, Severe, Not severe assigned score were 3, 2, 1 respectively. The total preference score for each content was calculated and mean score for particular constraints was worked out then ranking was done as the basis of percentage.

\section{Results and Discussion}

Table 1.Socio-economic profile characteristics of betel vine growers

\begin{tabular}{|r|l|l|l|l|}
\hline Sl.No. & \multicolumn{1}{|c|}{ Independent variable } & Category & Frequency & Percentage \\
\hline 1 & Age (In years) & Young <30 & 31 & 25.83 \\
\hline & & Middle 31-50 & 54 & 45.00 \\
\hline 2 & Education & Illiterate & 35 & 29.16 \\
\hline & & Primary and secondary & 28 & 17.50 \\
\hline & & High School & 47 & 23.33 \\
\hline 3 & Family size & Graduate and diploma & 24 & 39.17 \\
\hline & & Small (Up to 4) & 63 & 20.00 \\
\hline & & Medium (5-6) & 12 & 52.50 \\
\hline 4 & Annual income & Big (above 6) & 45 & 10.00 \\
\hline & & Low & 15 & 37.50 \\
\hline & & Medium & 72 & 12.5 \\
\hline 5 & Land holding & High & 33 & 60.00 \\
\hline & & Below 1 hectare & 17 & 27.50 \\
\hline & & $1-2$ hectare & 33 & 14.16 \\
\hline & & & 66 & 27.50 \\
\hline & & Above 3 hectare & 4 & 55.00 \\
\hline & & & 63 & 3 \\
\hline
\end{tabular}




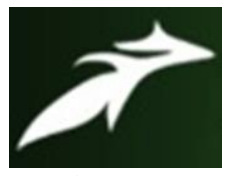

Athira Pradeep et al, International Journal of Advances in Agricultural Science and Technology, Vol.8 Issue.8, August-2021, pg. 52-59

ISSN: 2348-1358

Impact Factor: 6.057

NAAS Rating: 3.77

\begin{tabular}{|l|l|l|l|l|}
\hline 6 & No. of Trainings attended & No trainings attended & 23 & 19.16 \\
\hline & & $1-2$ trainings & 91 & 75.83 \\
\hline & & More than 2 trainings & 6 & 5.00 \\
\hline 7 & Mass media exposure & Low (Daily) & 17 & 14.16 \\
\hline & & Medium (sometimes) & 84 & 70.00 \\
\hline & & High (Never) & 19 & 15.83 \\
\hline 8 & Social participation & Low (No membership) & 12 & 10.00 \\
\hline & & $\begin{array}{l}\text { Medium( Atleast in one } \\
\text { organization) }\end{array}$ & 94 & 78.33 \\
\hline & & $\begin{array}{l}\text { High (More than one } \\
\text { organization) }\end{array}$ & 14 & 11.66 \\
\hline 9 & Extension contact & Low (Regularly) & 15 & 12.5 \\
\hline & & Medium (Occasionally) & 72 & 60.00 \\
\hline & & High (Never) & 33 & 27.50 \\
\hline 10 & Risk bearing capacity & Low & 20 & 16.66 \\
\hline & & Medium & 61 & 50.83 \\
\hline & & High & 39 & 32.50 \\
\hline
\end{tabular}

From the above table 1, It can be identified that Majority of the respondents were middle aged (45\%), followed by old aged (29.16\%) and young age (25.83\%). Higher percentage of the respondents $(39.17 \%)$ had completed high school education, followed by primary and secondary (23.33\%), graduate and diploma (20\%) and only 17.50 per cent were illiterate. Half of the respondents had small size of family $(52.50 \%)$, followed by high $(37.50 \%)$ and medium (10\%) size of family .Majority of the respondents earns medium level of annual income (60\%), followed by high (27.50\%) and low (12.50\%) level of annual income.

More than half of the respondents possessed nuclear family (55.83\%), followed by joint family (44.17\%).Eventually most of the respondents possess a land holding of 2-3 hectares (55\%), followed by $1-2$ ha land holding $(27.50 \%)$, below 1 ha land holding $(14.16 \%)$ and only 3.33 per cent had land holding of above 3 ha. 70 per cent of the respondents had medium level of mass media exposure, followed by 15.83 per cent had high level and 14.16 per cent had low level of mass media exposure respectively. 


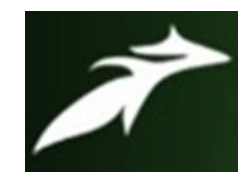

Athira Pradeep et al, International Journal of Advances in Agricultural Science and Technology, Vol.8 Issue.8, August-2021, pg. 52-59

ISSN: 2348-1358

Impact Factor: 6.057

NAAS Rating: 3.77

Majority of the respondents had medium level of extension contact (60\%), followed by high and low level of extension contact $(27.50 \%, 12.50 \%)$ respectively. Half of the respondents had medium level of risk bearing capacity $(50.83 \%)$, followed by high $(32.50 \%)$ and low $(16.66 \%)$ level of risk bearing capacity. More than three-fourth of the respondents had medium level of social participation (78.33\%), followed by high (11.66\%) and low (10\%) level of social participation. Somewhat similar results are found with the above results are Chandra and Sagar, 2004).

The Constraints of betel vine growers was studied on cultivation practices and the results were presented in table.2. and fig. 1.

\begin{tabular}{|c|l|c|c|c|c|c|c|}
\hline \multirow{2}{*}{ S. No } & \multirow{2}{*}{ Operations } & \multicolumn{6}{|c|}{ Response } \\
\cline { 3 - 8 } & & Very severe & \multicolumn{2}{c|}{ Severe } & \multicolumn{2}{c|}{ Not severe } \\
\cline { 3 - 8 } & & $\boldsymbol{f}$ & $\boldsymbol{\%}$ & $\boldsymbol{f}$ & $\boldsymbol{\%}$ & $\boldsymbol{f}$ & $\boldsymbol{\%}$ \\
\hline 1 & Land Preparation & 15 & 12.50 & 72 & 60.00 & 33 & 27.50 \\
\hline 2 & Manuring & 12 & 10.00 & 63 & 52.50 & 45 & 37.50 \\
\hline 3 & Planting Material & 12 & 10.00 & 94 & 78.33 & 14 & 11.66 \\
\hline 4 & Fertilizers & 30 & 25.00 & 88 & 73.33 & 2 & 1.66 \\
\hline 5 & Cultivation aspects & 20 & 16.67 & 77 & 64.17 & 23 & 19.17 \\
\hline 6 & Irrigation & 28 & 23.33 & 54 & 45.00 & 38 & 31.66 \\
\hline 7 & Weeding & 11 & 9.17 & 73 & 60.83 & 36 & 30.00 \\
\hline 8 & Diseases & 23 & 28.33 & 63 & 52.50 & 23 & 19.16 \\
\hline 9 & Harvesting & 34 & 28.33 & 57 & 47.50 & 29 & 24.17 \\
\hline
\end{tabular}

From table.2, it can be interpreted that 12.50 per cent of respondents thought that land preparation was very severe, followed by 60 per cent as sever and 27.50 as not severe. In respect to manuring, 10 per cent felt that was very severe, 52.50 per cent as severe and 37.50 per cent as not severe. 78.33 per cent, 11.66 per cent and 10 per cent as severe, not severe and very severe in respect to planting material. 73.33 per cent as severe, 25 per cent as very severe and 1.66 per cent as not severe in fertilizers are the constraints faced by respondents in cultivation practices. The lack of knowledge in cultivation aspects as severe $(64.17 \%)$, not severe $(19.17 \%)$, very severe (16.67\%) respectively. 


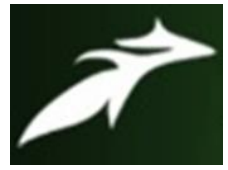

Athira Pradeep et al, International Journal of Advances in Agricultural Science and Technology, Vol.8 Issue.8, August-2021, pg. 52-59

ISSN: 2348-1358

Impact Factor: 6.057

NAAS Rating: 3.77

Meanwhile, 45 per cent, 31.66 per cent and 23.33 per cent felt that irrigation was very severe, not severe and severe respectively. 60.83 per cent, 30 per cent and 9.17 per cent of respondents felt that weeding as a severe, not severe and very severe constraint respectively. More than half of the respondents (52.50\%) as severe, 28.33 per cent as very severe and 19.16 per cent as not severe constraint. Nearly half of the respondents $(47.50 \%)$ felt that harvesting was severe, followed by 28.33 per cent as very severe and 24.17 per cent not severe constraint respectively. Somewhat similar findings were found in the studies of Biswas M et.al (2019).

Table 3. Overall distribution of constraints faced by the respondents in cultivation practices

\begin{tabular}{|c|c|c|c|}
\hline S. No. & Severity of constraints & Frequency & Per cent \\
\hline 1 & Very severe & 28 & 23.33 \\
\hline 2 & Severe & 54 & 45.0 \\
\hline 3 & Not severe & 38 & 31.66 \\
\hline
\end{tabular}

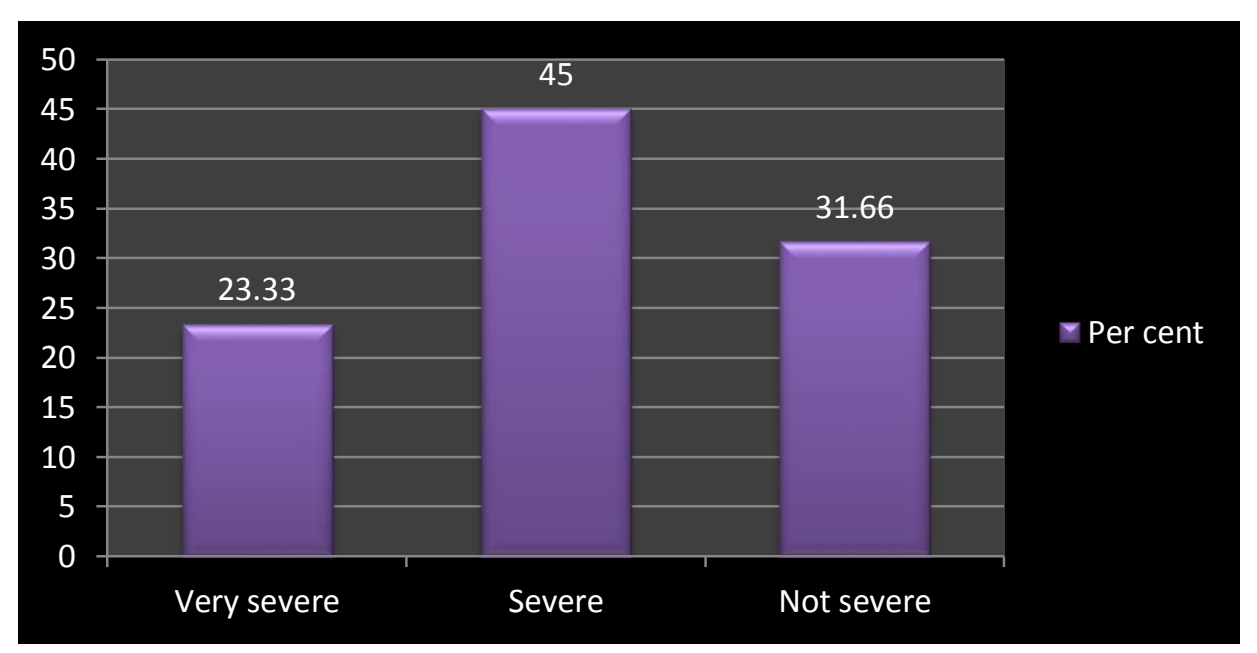

From the fig.1, Its found that, nearly half of the respondents felt the constraints were severe $(45 \%)$ in betel vine cultivation, followed by not severe $(31.66 \%)$ and very severe $(23.33 \%)$. 


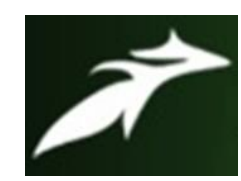

Athira Pradeep et al, International Journal of Advances in Agricultural Science and Technology, Vol.8 Issue.8, August-2021, pg. 52-59

ISSN: 2348-1358

Impact Factor: 6.057

NAAS Rating: 3.77

\section{Conclusion}

In conclusion, the study indicated that inadequate information regarding Betel vine cultivation management in the sampled areas, almost (45\%) grower's experienced labour shortage or high labour cost as the most problematic constraint, followed by price fluctuation, water scarcity, transportation and insects and diseases. In the study majority of the respondents were middle aged having high school education. The betel vine growers felt that labour cost and price fluctuation as the major problem, whereas insects and diseases is the least problem. The other constraints include storage facility, information availability and transportation. Most of the farmers suggested that co-operatives should be established, providing crop insurance, increasing awareness among the betel vine growers, provision of crop loan and subsidy and establishment of market intelligence. Majority of the respondents having medium level of annual income.70 per cent of the respondents had medium level of mass media exposure of the respondents had medium level of extension contact (60\%), Half of the respondents had medium level of risk bearing capacity $(50.83 \%)$, Nearly half of the respondents felt the constraints were severe $(45 \%)$ in betel vine cultivation, followed by not severe $(31.66 \%)$ and very severe $(23.33 \%)$. Based on the study following findings and recommendations are made for enhancing the profitably of betel vine cultivation in the study area that the farmers.

\section{References}

[1]. Amit Gupta. 2000. Economics of production and marketing of betel vine in Rewa district, Madhya Pradesh. M.Sc., thesis. J.N.K.V.V., Rewa.

[2]. Bharath Vittal Patil, Matoshri Bayabai., Shripatrao Kadam. And Kanya Mahavidyalaya., 2014, Management of Betel-vine's cost of cultivation, An international peer reviewed scholarly research journal for an interdisciplinary studies, ISSN 2278-8808, 2(81732)

[3]. Biswas, M., Saha, A., \& Dash, S. (2019). Sources of Information \& their extent of utilization by actors in akin for betel vine growers in Nadia district of west Bengal. Asian journal of agricultural extension, economics \& sociology, 32(4), 1-6.

[4]. Chandra, G. and Sagar, R. L. (2004). Harvesting green gold: Cultivation of betel vine in sundarban. Indian Farmers Digest, 37(3), 5-13.

[5]. Das, B.K. 2010. Incidence of Aleurocanthus spp. on betel vine and their interaction with host plants. The Journal of Plant Protection Sciences: 2 (2): 53-59.

[6]. Guha . P. (2004). Development of technology for enhancing shelf life of Betel leaves, Annual report of All India Coordinated Research Project on post harvest technology (ICAR). IIT, Kharagpur (Ed), Food and Agriculture Engineering Department, IIT, Kharagpur, India, pp 39-56.

[7]. Guha, P., 2006, Betel leaf: The Neglected Green Gold of India, Journal of Human Ecology, 19(2):87-93.

[8]. Guha, P. and Jain, R.K.: Status Report On Production, Processing and Marketing of Betel Leaf (Piper betle L.). Agricultural and Food Engineering Department, IIT, Kharagpur, India (1997). 


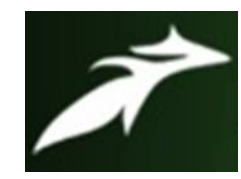

Athira Pradeep et al, International Journal of Advances in Agricultural Science and Technology,

Vol.8 Issue.8, August-2021, pg. 52-59

ISSN: 2348-1358

Impact Factor: 6.057

NAAS Rating: 3.77

[9]. Mallappa, Chandaragi, and R. K. Patil. (2014). "Population dynamics of Giant African Snail, Achatina fulica Bowditch (Stylommataphora:Achatinidae) in Betel vine ecosystem." Journal of Experimental Zoology, India 17.1 285-288.

[10].Masud, Md Zakaria, et al. (2020). "Morphology, Prevalence and Pathogenicity of Fungi Associated with Diseased Betel Vine (Piper betel L.) In Bangladesh." European Journal of Biology and Biotechnology 1.6

[11].Pavithra, H.K. 2016. An economic analysis of production and marketing of betel leaf- a study in Tumkur District, Karnataka. M.Sc., thesis. University of Agricultural Sciences, Bangalore - 560065.

[12].Pavithra, H.K,(2019). An Economic Analysis of Production and,Marketing of Betel vine

[13].B. V Patil, "Challenges before Betel Vine Cultivation", Scholarly Research Journal for Interdisciplinary Studies, Vol. 4, No. 25, pp. 2391-2400, 2015.

[14].S. Sripradha, "Betel Leaf - The Green Gold", Journal of Pharmaceutical Sciences and Research, Vol. 6, No. 1, pp. 36 - 37, 2014.

[15].Tholkappian, C., 2014, Production Function and Returns Organic and Conventional Betel leaf Cultivation: A Case Study of Thanjavur District in Tamil Nadu, International Journal of Recent Research and Applied studies, 5(3): ISSN 2349- 4891. 